\title{
Komunikasi Konseling Pada Program Dharma Wacana Dan Dharma Tula Di Dusun Ngis Kecamatan Narmada
}

\author{
Oleh: \\ Sayu Kadek Jelantik \\ Institut Agama Hindu Negeri Gde Pudja Mataram \\ Email: sayujelantik@ stahn-gdepudja.ac.id
}

\begin{abstract}
Counseling communication in the Dharma Wacana and Dharma Tula programs is an educational program for Hindus in internalizing Hindu religious teachings that are sourced from the Vedic Scriptures. Dharma discourse is one of the communication tools for Hindus in conveying Vedic teachings to direct and solve all Hindu problems so that it becomes an effective Hindu counseling communication model. This study describes the process of counseling communication in the Dharma Wacana and Dharma Tula programs in Dusun Ngis, Narmada District. This type of qualitative descriptive research uses the expose facto method. The concept of dharma wacana and dharma tula as tools for education and to Hindus in Indonesia in the form of Hindu religious speeches in the Guidance and counseling program is a personal, interpersonal, and group approach. The program of dharma wacana and dharma tula in guidance and counseling-based communication methods does not only help individuals or groups of Hindus solve life problems, but its main purpose is to change religious thought patterns and behavior and strengthen the spiritual-religious dimension of Hindus. The value messages of Hindu teachings originating from the Wedas are implemented in religious life which is conveyed in the Dharma Wacana Program based on Guidance and Counseling in Ngis Hamlet, Narmada District, which is the object of study in this study. The author found that it is not uncommon for the resource person to provide answers to the listener's questions by using the counseling communication model in the Dharma Wacana and Dharma Tula programs. The communication model referred to mainly in the use of spoken language as a communication tool with a counseling character. This is because the activities of dharma discourse in which the use of spoken language is a determinant of the effectiveness of answering a problem presented by the listener.
\end{abstract}

Keywords: Communication, Counseling, Dharma Discourse, Dharma Tula

\section{Pendahuluan}

Komunikasi yang merupakan proses penyampaian pesan dari seorang komunikator kepada komunikan kini telah mengalami transformasi keilmuan seiring dengan kompleksitas dinamika kehidupan manusia, salah satunya adalah model komunikasi berbasis bimbingan dan konseling yang memberikan ruang yang dilakukan untuk menemukan alternatif solusi dari berbagai fenomena dinamika kehidupan manusia. Program dharma wacana dan dharma tula yang menggunakan pendekatan komunikasi konseling merupakan pelayanan umat tidak akan terlepas dari proses bimbingan dan 
konseling selama program dharma wacana dan dharma tula berlangsung, hal ini senantiasa sangat mempengaruhi berjalanannya bimbingan dan konseling sekaligus merupakan keunikan bimbingan dan konseling itu sendiri. Model komunikasi berbasis bimbingan dan konseling juga diterapkan dalam kegiatan dharma wacana dan dharma tula oleh umat Hindu di Nusantara. Dharma wacana merupakan bagian dari kehidupan beragama Umat Hindu di Indonesia yang merupakan salah satu metode komunikasi paling efektif digunakan untuk mengedukasi dan memberikan bimbingan dan konseling kepada Umat Hindu. Dharma Wacana memang sudah bukan hal asing di tengah kehidupan keberagamaan masyarakat sebagai kegiatan yang berperan dalam pengembangan, penyebaran ajaran Hindu yang bersumber dari Weda. Dalam berbagai pandangan kegiatan dharma wacana diakui sudah saatnya dilakukan dalam berbagai bentuk dan melalui berbagai media. Para intelektual Hindu dan pendharmawacana juga telah banyak mendiskusikan bagaimana kegiatan dharma wacana dikelola sedemikian rupa sehingga di tengah era globalisasi dengan berbagai tantangan, dharma wacana akan tetap eksis dan memberi konstribusi bagi Umat Hindu dalam hal penguatan Panca Sradha.

Program Dharma Wacana yang cerdas di zaman kali yuga saat ini yang dimaksud membutuhkan manajemen dan kreativitas dalam penguatan strategi program dharma wacana di tengah kehidupan masyarakat modern yang sarat dengan globalisasi dalam berbagai bidang kehidupan. Sementara kegiatan bimbingan dan konseling Hindu masih belum banyak dikenal oleh masyarakat Hindu. Model komunikasi berbasis Bimbingan dan Konseling hakekatnya merupakan kegiatan layanan bantuan dan pendampingan seorang yang ahli dalam bidang public speaking terhadap individu atau kelompok dalam mengembangkan kepribadian dan atau menyelesaikan suatu permasalahan dengan pendekatan psikologis. Pendekatan psikologis sebagai sebuah pendekatan karena persoalan yang dihadapi sangat terkait dengan problem psikis individu atau kelompok yang disebabkan oleh suatu permasalahan kehidupan. Dengan berlandaskan ajaran suci Weda, para pembimbing dan pendamping berupaya memberikan bantuan penyelesaian permasalahan yang dihadapi umat Hindu dalam praktek kehidupan beragama.

Program Dharma Wacana dengan model komunikasi berbasis bimbingan dan konseling adalah dua hal yang berbeda, Namun sebenarnya keduanya dapat dipertemukan 
pada titik tujuan dan proses penyampaian suatu nilai kehidupan dan nilai-nilai agama kepada orang lain dengan tujuan tercerahkannya seseorang dengan nilai-nilai tersebut. Dengan demikian akan menjadikan seseorang menjadi lebih baik dalam menjalani kehidupan beragama dan memahami penerapan keimanan dalam konteks problem solving. Dalam kalangan masyarakat beragama Hindu, fenomena tersebut merupakan sebuah tantangan bagi para pendharmawacana atau para tokoh agama. Hal ini supaya para tokoh agama tidak hanya disibukkan dengan kegiatan upacara keagamaan saja tetapi mendalami diri dalam program dharma wacana yang terfokus pada kegiatan dibalik upacara keagaman. Metode komunikasi berbasis bimbingan dan konseling menyampaikan materi dharma wacana kepada para bhakta, atau dalam teori komunikasi dengan pola linier. Sudah saatnya seorang pendharma wacana melakukan pengembangan pola komunikasi dalam berdharma wacana. Terutama ketika melihat fenomena para bhakta yang merupakan lapisan masyarakat Hindu yang sedang mengalami suatu problem psikis atau sedang menghadapi suatu permasalahan dan membutuhkan dukungan mental sehingga secara psikis memberi pencerahan dalam penyelesaian masalahnya dalam program dharma wacana yang dilakukan.

Pola komunikasi dengan pendekatan bimbingan dan konseling inilah yang kemudian menjadi hal yang menarik untuk dapat dikembangkan dalam keragaman model komunikasi dalam berdharma wacana. Pola pembinaan Umat Hindu dalam program dharma wacana yang menerapkan model komunikasi berbasis bimbingan konseling untuk memecahkan segala permasalahan Umat Hindu yang terjadi di dalam kehidupan beragama ini terjadi di Dusun Ngis Kecamata Narmada. Dari Observasi awal yang dilakukan menggambarkan kondisi masyarakat Hindu Dusun Ngis yang minim akan pengetahuan agama, yang mengakibatkan banyak terjadi pernikahan beda agama yang menarik Umat Hindu untuk berpindah agama, tingkat Pendidikan yang masih rendah, dan pola didik masyarakat yang masih minim akan pengetahuan agama Hindu dirasa perlu untuk diberikan bimbingan dan konseling terkait fenomena yang terjadi. Oleh karena itu dalam tulisan ini penulis akan menfokuskan penelitian pada kegiatan program dharma wacana yang dilakukan pada kegiatan pengabdian dalam rangka bimbingan konseling permasalahan Umat Hindu di Dusun Ngis Kecamatan Narmada. 
Pesan-pesan yang mengandung ajaran agama hindu yang bersumber dalam Kitab Suci Weda dirangkai menjadi naskah dharma wacana yang merupakan ungkapan dan cara narasumber mengkomunikasikan pesan pesan nilai yang terkandung dalam jawaban atas pertanyaan para bhakta yang merupaka masyarakat Dusun Ngis Kecamatan Narmada yang dilanjutkan pada sesi Dharma Tula yang merupakan sesi tanya jawab atau dialoq interakatif Pendharma wacana kepada para bhakta. Dialog Interaktif tersebut menggunakan pendekatan konseling disamping menjelaskan atau menjawab permasalahan pendengar yang terkait dengan permasalahan yang terjadi di kehidupan beragama Umat hindu di Dusun Ngis Kecamatan Narmada. Pendekatan konseling dapat dilihat pada penyampaian jawaban narasumber yang selain memberikan jawaban dan penjelasan secara factual terhadap kondisi masyarakat yang telah diobservasi dari awal terkait dengan pertanyaan para bhakta, juga memberikan pesan-pesan motivasi yang akan membantu pendengar memiliki kepercayaan diri yang kuat dalam mengambil suatu keputusan yang tidak menyimpang dari etika beragama Hindu. Dalam kerangka inilah tulisan ini akan memaparkan model komunikasi berbasis bimbingan konseling pada program dharma wacana di Dusun Ngis Kecamatan Narmada. Dalam konteks komunikasi konseling inilah, penulis mengajukan persoalan yang akan menjadi bahasan dalam tulisan ini yaitu, bagaimana proses komunikasi konseling pada program dharma wacana dan dharma tula di Dusun Ngis Kecamatan Narmada? Tulisan ini bertujuan untuk memaparkan proses komunikasi konseling pada program dharma wacana dan dharma tula di Dusun Ngis Kecamatan Narmada.

\section{Metode}

Penelitian ini merupakan jenis penelitian kualitatif deskriptif dengan metode Expose Facto. Menurut Sugiyono (2010: 07), Penelitian ex post facto adalah suatu penelitian yang dilakukan untuk meneliti peristiwa yang telah terjadi dan kemudian dan mengkaji peristiwa yang telah terjadi untuk mengetahui faktor- faktor yang dapat menimbulkan kejadian tersebut. Dengan metode penelitian kualitatif expose facto ini mengkaji program dharma wacana yang dilakukan pada kegiatan pengabdian kepada masyarakat yang berlokasi di Dusun Ngis Kecamatan Narmada. Dalam penelitian ini, 
penulis menggunakan pendekatan kualitatif dengan metode deskriptif. Penulis ingin menggambarkan hasil penelitian yang ditemukan melalui tahapan teknik pengumpulan data yang dilakukan, yaitu wawancara, observasi, dan studi penelusuran dokumentasi. Teknik pengumpulan data dalam penelitian kualitatif adalah dengan melakukan observasi, wawancara mendalam, dan studi dokumentasi. Observasi yang dilakukan dalam penelitian ini adalah pengamatan. Pengamatan dilakukan dengan cara non participant observation, terhadap objek yang diteliti. Wawancara Mendalam (depth interview) yang dilakukan penulis dalam penelitian dimaksudkan untuk mengetahui pandangan, kejadian, kegiatan, pendapat, perasaan dari narasumber (subjek matter expert). Studi Penelusuran Dokumentasi dalam penelitian ini diperlukan terutama untuk memperkaya landasan-landasan teoritis dan mempertajam analisis penelitian yang berkaitan komunikasi bimbingan dan konseling pada program dharma wacana disertai dharma tula dalam kegiatan pengabdian masyarakat di Dusun Ngis Kecamatan Narmada.

\section{III.Pembahasan}

Komunikasi Konseling secara etimologi terdiri dari dua kata, yaitu Komunikasi dan Konseling. Komunikasi dan konseling memiliki arti yang berbeda tetapi jika digabungkan akan menjadi kesatuan makna yang saling berkaitan. Berikut pengertian komunikasi dan konseling menurut para ahli :

\section{Pengertian Komunikasi}

Stephen, W (2009, 4-5) memberikan tiga konseptual yang membentuk dimensi dasar komunikasi, yakni : a. Dimensi Pengamatan Atau Keringkasan yaitu definisi komunikasi berdasarkan kategori pengertian yang masih umum, luas dan bebas. Misalnya, definisi komunikasi sebagai proses penyatuan antara bagian bagian yang terputus, dalam hal ini adalah antara invidu yang satu dengan yang lain saling bersambung oleh karena adanya komunikasi. b. Dimensi Tujuan yaitu dimensi definisi komunikasi yang menggambarkan proses pengiriman dan penerimaan pesan dengan maksud tertentu. Misalnya, definisi komunikasi yang menerangkan tentang ,situasi-situasi tersebut merupakan sebuah sumber yang mengirimkan sebuah pesan kepada penerima dengan tujuan tertentu untuk mempengaruhi perilaku penerima. c. Dimensi Penilaian Normatif 
adalah definisi komunikasi yang menyertakan pernyataan tentang keberhasilan, kefektifan, atau ketepatan. Misalnya, komunikasi didefinisikan ,komunikasi merupakan pertukaran sebuah pemikiran atau gagasan. Asumsinya adalah sebuah pemikiran atau gagasan berhasil ditukarkan. komunikasi adalah penyampian suatu ide, pesan, informasi melalui sebuah simbol atau isyarat dari individu ke individu lainnya,

Pengertian Konseling Pendapat para ahli mengenai pengertian konseling adalah sebagai berikut (Prayitno 2013, 100): a. Lewis Konseling merupakan proses mengenai individu yang sedang mengalami masalah (klien) dibantu untuk merasa dan bertingkah laku dalam suasana yang lebih menyenangkan melalu interaksi dengan seseorang yang tidak bermasalah yang menyediakan informasi dan reaksi reaksi yang merangsang klien untuk mengembangkan tingkah laku yang memungkinkannya berperan secara lebih efektif bagi dirinya sendiri dan lingkungannya. b. Division of Counseling Psychology Konseling merupakan suatu proses untuk membantu individu mengatasi hambatanhambatan perkembangan dirinya dan untuk dan untuk mencapai perkembangan optimal kemampuan pribadi yang dimilikinya. Proses tersebut dapat terjadi setiap waktu. c. Maclean Konseling merupakan suatu proses yang terjadi dalam hubungan tatap muka antara seseorang individu yang terganggu oleh karena masalah-masalah yang tidak dapat diatasinya sendiri dengan seseorang pekerja yang profesional, yaitu orang yang telah terlatih dan berpengalaman membantu orang lain mencapai pemecahan terhadap berbagai jenis kesulitan pribadi. d. Ahmad Juntika Nur Ihsan Konseling berarti upaya membantu individu melalui proses interaksi yang bersifat pribadi antara konselor (individu yang memiliki keahlian dalam mengarahkan pihak yang memiliki maslah) dan konseli (individu yang sedang memiliki maslah) mampu memahami dirinya sendiri dan lingkungannya, mampu membuat keputusan dan menentukan tujuan berdasarkan nilai yang diyakininya sehingga konseli merasa bahagiadan efektif perilakunya. Dari definisi konseling yang dipapakarkan oleh para ahli, dapat disimpulkan bahwa konseling merupakan upaya pemberian bantuan kepada individu yang sedang mengalami sebuah masalah atau hambatan dalam proses perkembangannya (klien) oleh individu lain yang sudah terlatih dan profesional dalam mengarahkan klien (konselor) dengan proses tatap 
SADHARANANIKARANA:

Jurnal Ilmiah Komunikasi Hindu Institut Agama Hindu Negeri Gde Pudja Mataram
Volume 3, Nomor 1 Tahun 2021 2338-8382 (ISSN Cetak)

https://e-journal.iahn-gdepudja.ac.id/index.php/SN

muka agar klien mampu memahami dirinya sendiri guna penyelesaian masalah dan hambatannya agar tidak terjadi hal yang serupa di waktu yang akan datang.

Dari kedua definisi komunikasi dan konseling yang telah dipaparkan di atas maka dapat disimpulkan komunikasi konseling adalah penyampaian pesan, ide atau informasi antara konselor dengan klien selama proses pemberian bantuan berlangsung, yang berdampak pada perubahan tingkah laku. Komunikasi konseling yang diterapkan dalam pelaksanaan dharma wacana dan dharma tula di kegiatan pengabdian kepada masyarakat oleh para Dosen jurusan Dharma Duta STAHN Gde Pudja Mataram dengan proses komunikasi konseling yang dapat dijelaskan dalam bagan berikut ini:

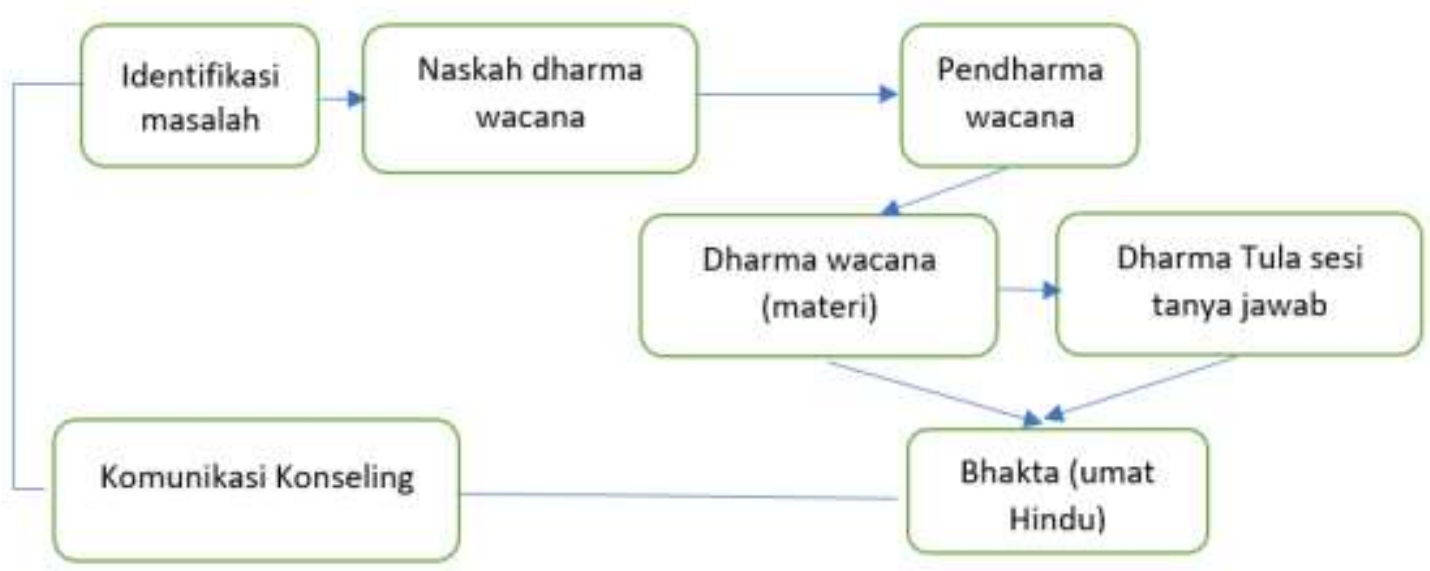

Penelitian dilakukan di Dusun Ngis Desa Buwun Sejati Kecamatan Narmada, dimana kegiatan Dharma wacana dan Dharma Tula dilakukan di Banjar Kelodan, pemilihan lokasi ini berdasarkan survey dan observasi yang dilakukan oleh peneliti yang berkaitan dengan serangkaian kegiatan pengabdian kepada masyarakat yang dilakukan oleh dosen Prodi Penerangan STAHN Gde Pudja Mataram.

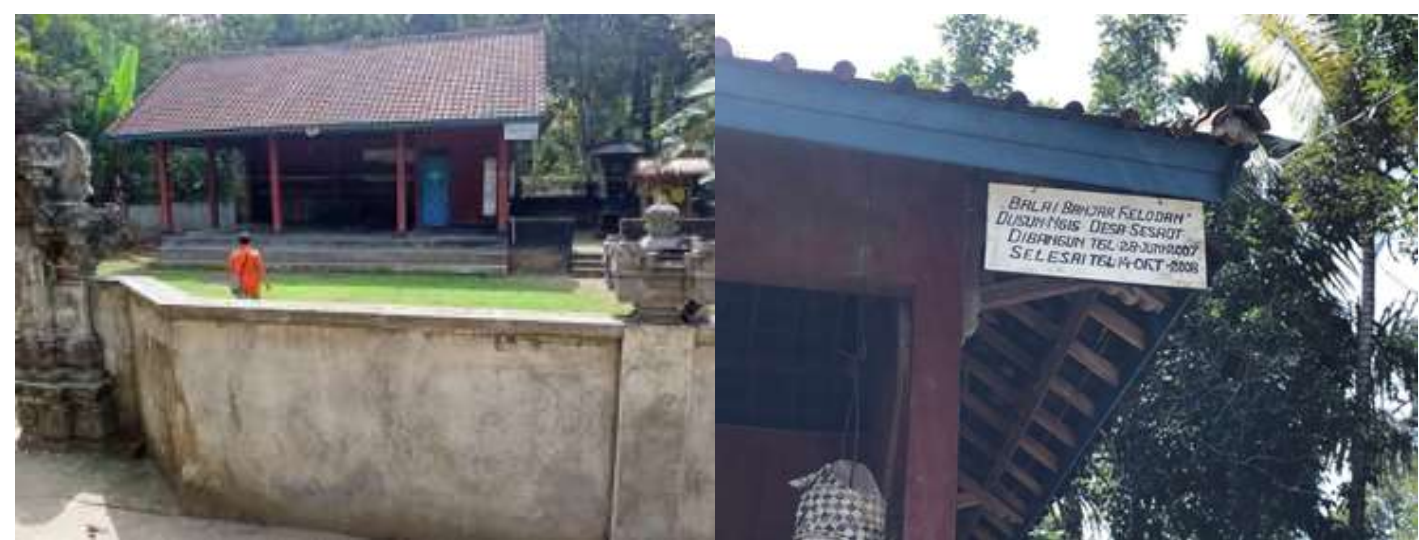


SADHARANANIKARANA:

Jurnal Ilmiah Komunikasi Hindu Institut Agama Hindu Negeri Gde Pudja Mataram
Volume 3, Nomor 1 Tahun 2021 2338-8382 (ISSN Cetak)

https://e-journal.iahn-gdepudja.ac.id/index.php/SN

Gambar 1. Lokasi penelitian

Proses awal dalam komunikasi konseling yang dilakukan di Dusun Ngis Kecamatan Narmada yaitu dengan mengidentifikasi permasalahan yang dialami, observasi dan wawancara menjadi cara dalam mengidentifikasi permasalahan umat. Dari hasil wawancara dengan Kepada Dusun Ngis Kecamatan (12 September 2020):

"Permasalahan utama yang terjadi di dusun kami adalah banyaknya pernikahan beda agama yang terjadi, dimana anak-anak kita yang masuk ke agama lain. Dan sering kali pernikahan beda agama ini menjadi sumber masalah dan konflik di kalangan masyarakat hindu dan muslim yang memang menjadi satu wilayah bagian di Dusun Ngis ini. Setelah konflik pernikahan ini juga berkembang menjadi konflik di intern umat kita dimana proses upacara mepamit bisa dilakukan atau tidak masih menjadi dilemma yang belum terjawab di masyarakat kami sampai saat ini, Sehingga besar harapan kami para dosen STAH dapat memberikan bimbingan dan solusi yang dialami oleh umat kami”. Hasil wawancara diperkuat dengan bukti dokumentasi berikut ini:

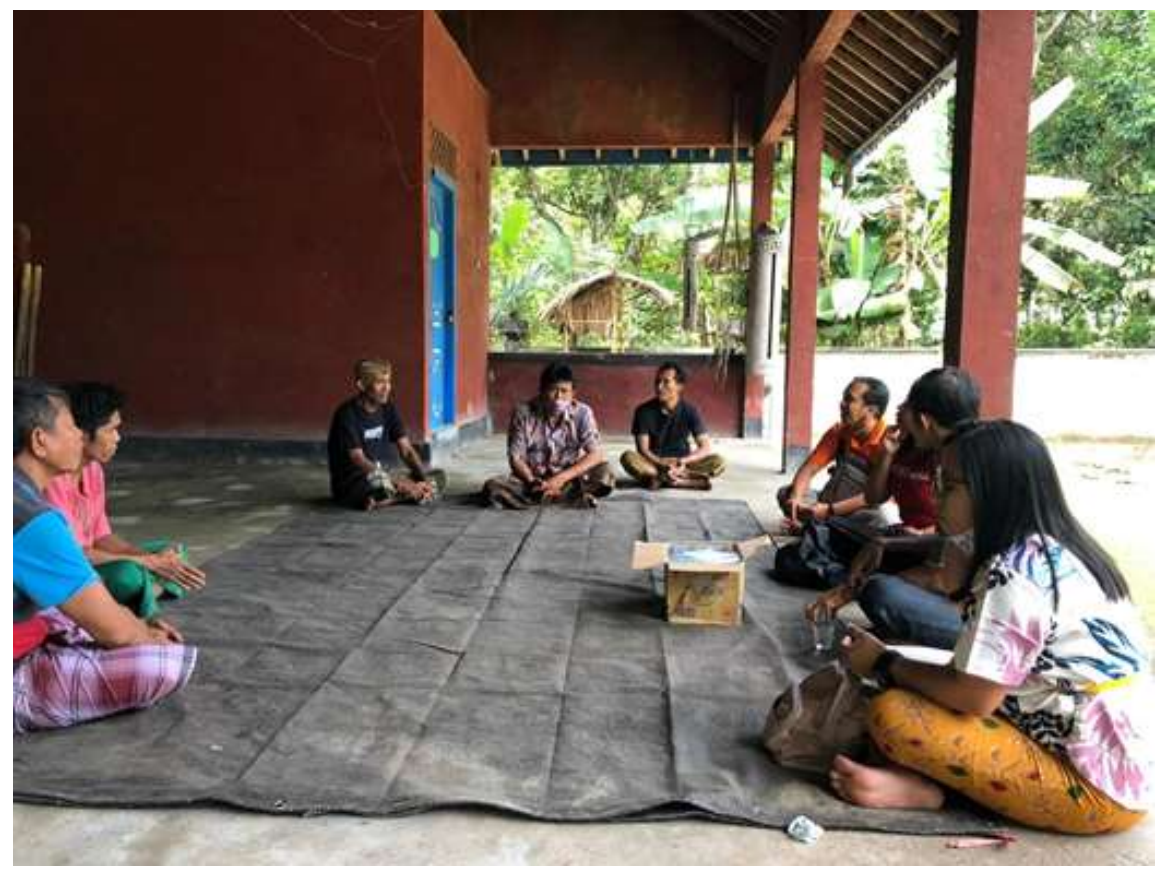

Gambar 2. Kegiatan observasi awal dan wawancara kepala Dusun Ngis

Proses wawancara merupakan proses komunikasi konseling dimana kepala dusun mengambarkan kondisi terkini tentang umatnya dimana sudah mengalami dinamika nilai kehidupan beragama dan sosial kemasyarakatan. Nilai-nilai yang dianut masyarakat 
SADHARANANIKARANA:

Jurnal Ilmiah Komunikasi Hindu Institut Agama Hindu Negeri Gde Pudja Mataram
Volume 3, Nomor 1 Tahun 2021 2338-8382 (ISSN Cetak)

https://e-journal.iahn-gdepudja.ac.id/index.php/SN

dalam kehidupan sosial terdapat berbagai macam nilai termasuk nilai-nilai luhur menausiaan yang dianut oleh masyarakat Dusun Ngis yang mengatur sister kehidupan sehari-hari. Nilai-nilai luhur yang hidup dan berkembang di Dusun Ngis yakni hal-hal yang dianggap penting, benar dan dijunjung tinggi oleh masyarakat serta secara sadar ataupun tidak dijadikan pedoman dalam menjalani kehidupan, tolak ukur dan orientasi dalam kehidupan oleh kelompok masyarakat dalam bersikap dan berperilaku. Kebutuhan utama masyarakat yang sangat penting bagi para pembimbing karena berkaitan erat dengan masalah motivasi dan upaya memotivasi masyarakat untuk bergerak secara aktif ke arah tujuan pembinaan yang hendak dicapai. Adapun kebutuhan yang mendorong proses perubahan di masyarakat biasanya terjadi karena, pertama, merasakan sendiri adanya kekurangan yang perlu dipenuhi. Kedua, sengaja disadarkan kekurangan dan kebutuhan-kebutuhannya. Ketiga, pengaruh dari pergaulan dan contoh yang diamati, keempat, rekayasa terencana untuk menawarkan kebutuhan-kebutuhan baru, dan kelima, pergeseran nilai hidup yang menimbulkan berbagai tuntutan.

Tahap selanjutnya setelah observasi awal dan wawancara kepada Kepala Dusun Ngis Kecamatan Narmada yaitu menyusun naskah dharma wacana yang akan dilakukan oleh salah satu dosen Prodi Penerangan yaitu Drs. Ida bagus Heri Juniawan, M.Si. Kegiatan dharma wacana dan dilanjutkan dengan kegiatan dharma tula. Dharma wacana dilaksanakan pada tanggal 18 September 2020, dengan tema dharma wacana "Hukum dan Adat Istiadat Pernikahan Beda Agama" diperjelas pada gambar di bawah ini:

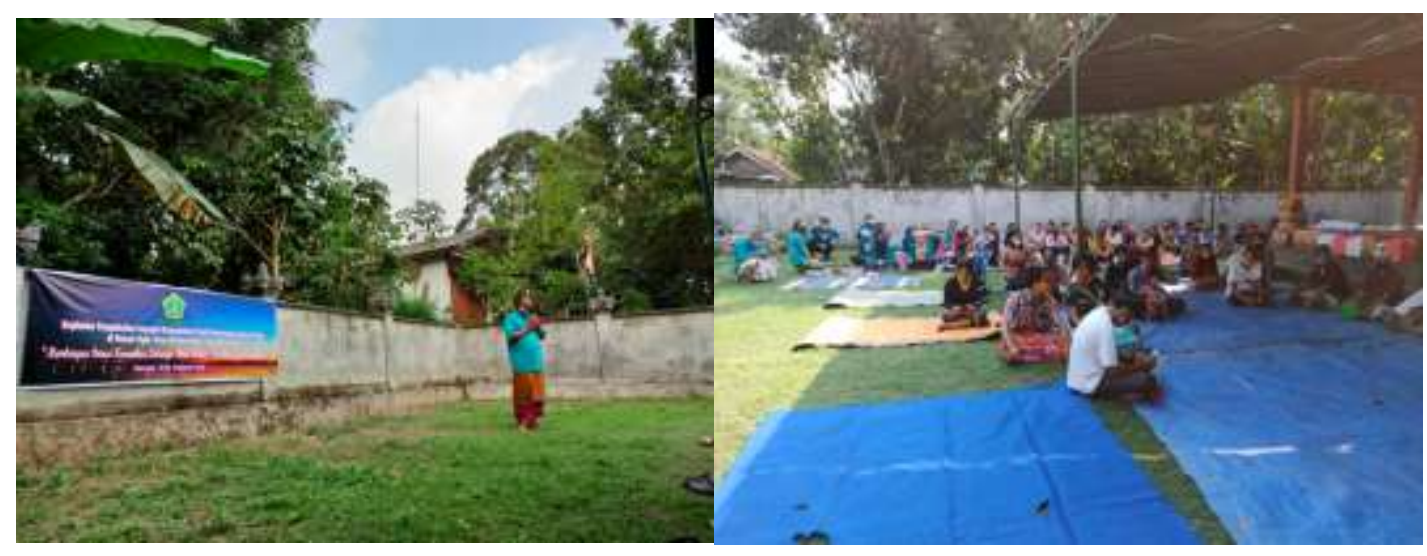

Gambar 3. Proses Dharma Wacana dan Dharma Tula

Dalam proses dharma wacana dan dharma tula peran seorang pendharma wacana sangatlah besar, karena skill dan empati seorang pendharma wacana harus tercermin 
dalam proses dharma wacana dan dharma tula berlangsung. Jalaluddin Rahmat $(2005$;257) dalam bukunya Psikologi Komunikasi mengutarakan pendapatnya tentang kredibilitas komunikator, beliau menyatakan, Kredibiltas (komunikator) adalah seperangkat persepsi komunikate tentang sifat-sifat komunikator. Sehingga pendharma wacana memiliki skill yang terkandung yaitu ada dua hal : (1) kredibilitas adalah persepsi komunikate; jadi inheren dalam diri komunikator; (2) Kredibilitas berkenaan dengan sifat-sifat komunikator, yang selanjutnya akan kita sebut sebagai komponen kredibilitas. Selanjutnya menurut Jalaludin Rakhmat (2005: 260) komponen-komponen kredibilitas adalah (1) Keahlian, adalah kesan yang dibentuk komunikan tentang kemampuan komunikator dengan hubungannya dengan topik yang dibicarakan. Komunikator yang tinggi pada keahliannya dianggap cerdas, mampu, ahli, berpengalaman, dan terlatih. (2) Kepercayaan, adalah kesan komunikan tentang komunikator yang berkaitan dengan wataknya ( Jujur atau tidak jujur, tulus atau lancung, dan sebagainya). Aristoteles menyebutnya "good moral character", sedang Quintillianus menyebutnya "a good man speaks well". Sedangkan menurut Koehler, Annatol, dan Applbaum (Rakhmat, 2005: 260), komponen kredibilitas itu ditambah lagi dengan (1) Dinamisme, berkenaan dengan cara berkomunikasi, bergairah, bersemangat, aktif, tegas, dan berani. Dinamisme memperkokoh kesan keahlian dan kepercayaan; (2) Sosiabilitas, adalah kesan komunikan tentang komunikator sebagai orang yang periang dan suka bergaul; (3) Koorientasi, adalah kesan komunikan tentang komunikator sebagai orang yang mewakili kelompok dan nilai-nilai dari komunikan; (4) Kharisma, menunjukkan suatu sifat luar biasa yang dimiliki komunikator."

Tahap selanjutnya, para informan yakni para bhakta yang merupakan Umat Hindu di Dusun Ngis Kecamatan Narmada diberikan waktu untuk mengutarakan permasalahan pribadi atraupun kelompok yang terjadi pada jalannya proses komunikasi konseling pada dharma tula yang diikutinya. Proses komunikasi konseling akan memperoleh feedback dan hasil yang berbeda antara satu bhakta dengan bhakta lainnya sesuai dengan kondisi diri yang dipaparkan. Dalam hal ini, penulis melihat adanya proses komunikasi yang berjalan dalam proses konseling pada program dharma wacana dan dharma tula yang terdiri dari konteks pesan verbal maupun nonverbal. Sebagaimana penjelasan dari Robert 
Manthei (1997: 2-3) yang menyebutkan bahwa keterampilan konseling merupakan kemampuan verbal dan nonverbal yang terfokus pada upaya mempengaruhi konseli melalui hubungan yang dilandasai kepedulian, rasa hormat dan optimisme, sehingga pada akhirnya konselilah yang menentukan sifat dari masalahnya, tujuan keberhasilan konseling yang hendak dicapainya. Nurlatifah (2016) menjelaskan dalam hasil penelitiannya tentang konseling sebagai jantung utama layanan bimbingan konseling tidak dapat dihindarkan dari komunikasi, mengingat konseling pada umumnya dilakukan dengan wawancara dan dialog secara intensif dan mendalam. Komunikasi menjadi salah satu faktor determinan bagi suksesnya konseling. Keterampilan komunikasi dalam ranah konseling dipelajari melalui komunikasi konseling, yaitu mengenai tatacara berkomunikasi dalam proses konseling. Keterampilan ini diinternalisasikan dalam diri konselor dengan memperhatikan berbagai aspek yang melingkupi konseli, termasuk budaya dan agamanya, sehingga proses assesment, pembentukan rapport, wawancara konseling, dan terminasi konseling dapat berlangsung secara efektif dan efisien. Komunikasi dikatakan efektif jika dapat mencapai tujuan dan dikatakan tepat apabila sesuai dengan yang diharapkan dalam suatu hubungan. Komunikasi yang efektif, menurut Bill Gudykunst, dapat meminimalisir kesalah pahaman (Griffin, 2003:423). Hal tersebut membawa pemahaman bahwa melalui komunikasi konseling yang tepat dan efektif, dapat terbangun hubungan terapeutik yang menyembuhkan serta tercapainya tujuan yang telah ditetapkan dalam konseling. Komunikasi konseling yang dilakukan secara akurat, cermat, penuh pemahaman, dan tanpa melewatkan informasi mengenai latar budaya dan agama membuat konselor dan konseli berada pada hubungan yang selaras sehingga dapat saling mempengaruhi satu sama lain. Kelancaran komunikasi yang peka budaya dan agama dalam konseling menjadi tanggung jawab konselo rkarena pada umumnya konselor dipandang telah kongruen, selaras, dan memiliki kapasitas untuk membantu konseli (Nurlatifah:2016).

Konselor diharapkan memiliki kemampunan dasar komunikasi konseling yang diwujudkan dalam kemampuan komunikasi intrapersonal selama proses konseling. Kemampuan ini bukan merupakan bakat dan bawaan sejak lahir, melainkan dikembangkan melalui belajar. Ketika berkomunikasi dengan konseli, konselor berjalan 
di antara diri sendiri dan konseli. Di satu sisi konselor dengan latar budaya dan agamanya mengekspresikan gagasan/sikapnya dengan jelas, di sisi lain konselor mendengarkan dan menghargai gagasan/sikap yang diekspresikan konseli menurut pemahaman dan latar budaya dan agama konseli (Nurlatifah: 2016). Dalam konteks penelitian yang dilakukan Nurlatifah (2016) di atas, penulis mengamati hasil penelitiannya yang menggambarkan adanya upaya yang diperlukan untuk membangun proses komunikasi antara konselor dan konseli yaitu dengan memerhatikan aspek budaya dan agama, melalui kutipan hasil penelitiannya sebagai berikut: Komunikasi konseling yang dilakukan secara akurat, cermat, penuh pemahaman, dan tanpa melewatkan informasi mengenai latar budaya dan agama membuat konselor dan konseli berada pada hubungan yang selaras sehingga dapat saling mempengaruhi satu sama lain. Kelancaran komunikasi yang peka budaya dan agama dalam konseling menjadi tanggung jawab konselor karena pada umumnya konselor dipandang telah kongruen, selaras, dan memiliki kapasitas untuk membantu konseli (Nurlatifah: 2016). Hal ini dipertegas juga dengan hasil wawancara penulis dengan salah satu informan (18 September 2020), yang menyatakan bahwa dalam proses konseling, hal yang tidak luput dari perhatiannya adalah dengan memerhatikan aspek pesan verbal dan nonverbal yang disampaikan oleh narasumbernya. Ini menandakan pentingnya isi pesan yang disampaikan komunikator dalam proses komunikasi konseling pada program dharma wacana dan dharma tula kepada para pesertanya, selaku komunikan.

Keterampilan komunikasi konseling bisa dikatakan sebagai teknik dan strategi konseling umat Hindu di Dusun Ngis Kecamatan Narmada, karena bagi seorang konselor pada kegiatan Dharma Wacana disebut dengan pendharma wacana memiliki keterampilan konseling. Dasar penyusunan naskah dharma wacana berdasarkan hasil observasi dan wawancara yang menjadi dasar menentukan tema dan materi yang pas untuk memberikan edukasi dan konseling bagi umat hindu yang sudah berkumpul di banjar Kelodan Dusun Ngis Kecamatan Narmada. (Willis, 2011: 157), Proses komunikasi konseling merupakan kunci keberhasilan untuk mencapai tujuan konseling. Seorang konselor yang efektif harus mampu merespon konseling dengan keterampilan yang benar, sesuai keadaan konsel saat 
itu. Respon yang baik adalah pernyataanpernyataan verbal dan nonverbal yang dapat menyentuh, merangsang dan mendorong sehingga konseli terbuka untuk menyatakan dengan bebas perasaan, pikiran dan pengalamannya. Selanjutnya konseling terus terlibat dalam mendiskusikan mengenai dirinya bersama konselor. Dalam program dharma wacana pendharma wacana bertindak sebagai konselor yang memberikan arahan dan solusi kepada klien yaitu umat Hindu yang ada Di Dusun Ngis Kecamatan Narmada.

Komunikasi Konseling Dalam bagian ini, penulis menggunakan beberapa referensi yang relevan tentang komunikasi konseling, tetapi yang hubungannya dengan program dharma wacana dan dharma tula. Pertama, pandangan dari Robert R. Charkhuff (2008: 252) yang menyatakan bahwa keterampilan konseling berperan sebagai media yang yang memfasilitasi mengeksporasi diri help (konseli) dalam mengidentifikasi dan mengoperasionalisasikan dimensi personalisasi konseli ke arah perubahan perilaku. Kedua, penjelasan Robert Manthei (1997: 2-3) yang menyebutkan bahwa keterampilan konseling merupakan kemampuan verbal dan nonverbal yang terfokus pada upaya mempengaruhi konseli melalui hubungan yang dilandasai kepedulian, rasa hormat dan optimisme, sehingga pada akhirnya konselilah yang menentukan sifat dari masalahnya, tujuan keberhasilan konseling yang hendak dicapainya. Ketiga dari pandangan Gerard Egan (2010: 125). Dalam melaksanakan bimbingan penyuluhan keagamaan dalam bentuk dharma wacana dan dharma tula, perlu benar-benar dikenali agar jelas hal-hal positif yang perlu ditingkatkan dan hal-hal negatif yang perlu dikurangi dan dihambat supaya tidak berkembang. Ada beberapa aspek yang layak untuk dipertimbangkan sebelum suatu gagasan tersebut didialogkan dengan realitas. Aspek-aspek tersebut meliputi nilai-nilai yang dianut, kebutuhan utama, hal-hal yang peka dan kondisi aktual dari suatu masyarakat.

Keterampilan konseling merupakan keterampilan komunikasi (communication skills) sebagai upaya membantu konseli untuk mengelola masalah dan mengembangkan kesempatan dalam dialog yang bersifat kolaboratif. Dalam kegiatan dharma tula masyarakat aktif dalam mengajukan pertanyaan dan diberikan jawaban oleh sang pendharma wacana sehingga komunikasi konseling bersifat interaktif, hal ini tertulis jelas pada notulensi kegiatan dharma wacana dan dharma tula di bawah ini: 
Dharma Wacana:

- Cinta yang menjadi dasar terjadi suatu pernikahan yang ideal

- Ketika cinta sudah mengesampingkan semua perbedaan maka terjadilah sebuah konflik batin yang luas bukan hanya antara dua insan yang dimabuk asmara tetapi melibakan keluarga besar kedua belah pihak.

- Pernikahan yang sejatinya akan mendatangkan kebahagiaan dan kedamaina jika berdasarkan pada pasal 2 Ayat 1 yaitu (1)"Perkawinan adalah sah, apabila dilakukan menurut hukum masing-masing agamanya dan kepercayaannya itu" (2)"Tiap-tipa perkawinan dicatat menurut peraturan perundang-undangan yang berlaku"

- Pernikahan yang terjadi dengan menarik pasangan dari keyakinan berbeda sering kali mendatangkan sebuah permasalahan keluarga yang harus diselesaikan dengan azas kekeluargaan musyawarah mufakat"

Dharma Tula:

1. Kepala Dusun Ngis "Ketika Umat Hindu sudah masuk muslim, kemudian dilakukan proses mepamit, apakah boleh masuk sanggah dan melaksanakan upacara tersebut?"

2. Bahwati "Hukum mana yang bisa diterapkan untuk menjadi dasar dalam upacara agama yang dilakukan ketika umat hindu sudah sah menganut agama lain, agar pedanda atau pinandita yang ditunjuk untuk muput tidak disalahkan dikemudian hari?"

3. Ni Komang pasek " pakah Hindu mengsahkan pernikahan beda agama, jika iya mana hukum hindu yang menyatakan seperti itu. Kedua bagaimana cara atau solusi untuk mengurangi dan menghentikan pernikahan beda agama yang terjadi?"

4. I Ketut Markas "menegaskan atas materi yang disampaikan dan jawaban yang disampaikan bahwa jika sudah masuk keyakinan berbeda tidak boleh melakukan proses mepamit secara agama, tetapi bisa dilakuakan jika terjadi suatu kesepakaan antara kedua keluarga besar atas dasar kemanusiaan"

Jawaban:

1. Secara agama tidak boleh, tetapi sebagai dasar kemanusiaan maka bisa dilakukan aas kesepakaan bersama keluarga besar

2. Pasal 2 ayat 1 merupakan paying hukum untuk melindungi kewajiban dan tugas pedanda dan pinandita, karena tidak boleh menduakan agama

3. Komunikasi keluarga sanga pening dan efekif dalam mencegah terjadinya pernikahan beda agama, penanaman ilmu agama dari dini sampai remaja.

Pemberian umpan balik merupakan metode yang sangat ampuh untuk meningkatkan mutu komunikasi konseling. Konselor yang disini bertindak sebagai pendharma wacana memberikan saran dan solusi langsung secara lisan kepada umat hindu (bhakta) pada saat berlangsungnya kegiatan dharma tula, feedback yang diberikan 
oleh para bhakta merupakan bukti bahwa pesan yang dikirimkannya itu akhirnya ditangkap dan di respon. Feedback dapat berupa tanda verbal dan nonverbal, konselor akan mencari tanda-tanda yang bentuknya bisa beraneka ragam. Mungkin berupa tanggapan verbal sebagaimana terjadi bila penerima meberikan jawaban. Mungkin juga berupa tangggapan nonverbal seperti pelaksanaan isi pesan, anggukan kepala, ekspresi wajah yang mnunjukkan bahwa penerima memahami isi pesan atau tidak memahaminya, menerima, mempertanyakan, atau bahkan menolak pesan yang disampaikan. Komunikasi yang efektif terjadi apabila pesan dapat diterima, dimengerti, dan dipahami sebagaimana yang dimaksud oleh penerimanya. Dalam prosesnya, klien mengungkapkan pesan mengenai masalahnya kepada konselor dengan harapan adanya respon dari konselor terhadap masalah yang dialaminya tersebut. Sebaliknya konselor menyampaikan pesanpesannya agar klien bersifat terbuka kepadanya dandiharapkan dapat terjadinya perubahan perilaku klien yang lebih baik yang dapat mendukung pemecahan masalah klien. Komunikasi konseling dapat dilaksanakan baik secara verbal maupun nonverbal atau secara dialog dan bahasa tubuh dalam suatu tujuan bersama yakni pemecahan masalah klien dan dapat membuat keputusan yang tepat.

\section{IV.Simpulan}

Program dharma wacana dan dharma tula yang merupakan salah satu kegiatan dari pengabdian kepada masyarakat yang dilakukan oleh Dosen Prodi Penerangan STAHN Gde Pudja Mataram dilakukan dengan pendekatan jenis komunikasi konseling. Dinamika kehidupan beragama yang paling menonjol terkait dengan pernikahan beda agama yang menyeret umat kita pindah agama yang lain. Dari fenomena inilah pendahrma wacana yang bertindak sebagai konselor memberikan materi dharma wacana yang dikemas untuk menjawab segala problematika kehidupan beragama di Dusun Ngis Kecamatan Narmada. Dilanjutkan dengan kegiatan dharma tula yang bersifat interaktif, dimana para bhakta berkesempatan langsung untuk memberikan pertanyaan dan diberikan langsung jawaban oleh pendharma wacana. Komunikasi konseling pada program dharma wacana dan dharma tula merupakan alat komunikasu yang paling efektif dilakukan untuk mengedukasi dan membimbing umat agar bisa menjalani kehidupan 
SADHARANANIKARANA:

Jurnal Ilmiah Komunikasi Hindu Institut Agama Hindu Negeri Gde Pudja Mataram
Volume 3, Nomor 1 Tahun 2021 2338-8382 (ISSN Cetak)

https://e-journal.iahn-gdepudja.ac.id/index.php/SN

bergama Hindu dengan lebih baik lagi sehingga permaslahan yang sering terjadi sebelumnya bisa diminimalisir dan menciptakan keharmonisan di kehidupan masyarakat Hindu di Dusun Ngis Kecamatan Narmada.

\section{Daftar Pustaka}

A.Griffin, Emory. 2003. A First Look at Communication Theory. Fifth Edition. McGrawHill. Boston.

Carkhuff, Robert R. 2008. The Art of Helping. Ninth Edition. Amherst. Possibilities Publishing, Inc. MA

Egan, Gerard. 2010. The Skilled Helper a Problem-Management and OpportunityDevelopment Approach to Helping. Ninth Edition. Brooks/Cole. Belmont, CA.

Manthei, Robert. 1997. Counselling The Skills of Finding Solutions to Problems. Routledge. London and New York.

Nurlatifah, Andar Ifazatul. 2016. Komunikasi Konseling Peka Budaya dan Agama. Jurnal Konseling Religi 7 (1): 231-258.

Prayitno. 2013. Dasar-Dasar Bimbingan dan Konseling. Jakarta: PT. Rineka Cipta.

Rakhmat, Jalaluddin. 2005. Psikologi Komunikasi. PT.Remaja Rosdakarya. Bandung Sugiyono. 2010. Metode Penelitian Kuantitatif Kualitatif dan R\&D. Bandung: Alfabeta.

Stephen W. Little Jhon \& Karen A. Foss. 2009. Teori komunikasi. Jakarta: PT. Salemba Humanika.

Willis, Sofyan S. 2011. Konseling Individual: Teori dan Praktek. Alfabeta. Bandung 